\title{
NEW DIRECTOR OF THE HENRY DUNANT INSTITUTE
}

On 8 July 1975, the General Meeting of the Henry Dunant Institute appointed as the Institute's new director Mr. Jean Pictet, Vice President of the International Committee of the Red Cross and associate professor at the University of Geneva. He succeeds Mr. Pierre Boissier, who was killed in an accident last year, after being the Institute's moderator since its beginning.

\section{REPORT ON THE XXIInd INTERNATIONAL CONFERENCE OF THE RED CROSS}

The International Review devoted its issue of January 1974 to the XXIInd International Conference of the Red Cross which took place at Teheran in 1973. It drew attention to the importance of that meeting, which, in the words of the President of the ICRC, took place "in an atmosphere of friendship, and unquestionably produced worthwhile results."

We revert to it therefore only to report the publication of a 145-page folio volume containing the complete record of the meeting of the Council of Delegates-which took place on 7 November 1973-and of the International Conference itself, whose five plenary sessions took place from 8 to 15 November. The work also contains the texts of the resolutions adopted.

The book is available in English, French and Spanish and is illustrated. It may be obtained, at a price of 25 Swiss francs, from the Red Lion and Sun Society of Iran. 